\title{
CYRILO-METODSKÝ KULT A RELIGIOZITA NA SLOVENSKU V 19. - 21. STOROČí
}

\author{
The Cyrillo-Methodian Cult and Religiosity in Slovakia \\ from the 19th to the 21st Century
}

\author{
Martin Hetényi
}

DOI: $10.17846 /$ CL.2019.12.1.141-158

\begin{abstract}
HETÉNYI, Martin. The Cyrillo-Methodian Cult and Religiosity in Slovakia from the 19th to the 21st Century. The paper focuses on the significance of the CyrilloMethodian cult and it is based on the findings of the long-term research. It deals with the diffusion and maintenance of cultural heritage of Ss. Cyril and Methodius in modern Slovak history. One of the aims of the paper is to study the impact of the Cyrillo-Methodian cult within a wider context of religiosity of social groups and classes in Slovakia. It presents some specific features of the cult of Ss. Cyril and Methodius and their disciples in Slovakia, and highlights the impact of the current church-political situation on the growth of the cult and its influence on political, church and other professional institutions. Synchronic and diachronic approach used in interdisciplinary research allowed a complex view on the spread of the cult in specific historical periods in Slovakia. Historical analysis is followed by the author's reflections on how the Cyrillo-Methodian cultural heritage relates to the religious ethical level. The Solun brothers' mission emphasised piety (and a religious worldview per se) typical for the eastern religiosity. The study tries to define several aspects of the brothers' work; especially those which deal with the growth of the spiritual essence of the society. As the Second Vatican Council and the documents of Pope John Paul II show, these issues remain topical and inspiring even today.
\end{abstract}

\section{Keywords: Cyrillo-Methodian tradition, modern Slovak history, religiosity}

\begin{abstract}
Abstrakt: HETÉNYI, Martin. Cyrilo-metodský kult a religiozita na Slovensku v 19. - 21. storoč́. Príspevok o význame cyrilo-metodského diela vznikol na základe dlhodobého výskumu. Orientuje sa na šírenie a udržiavanie kultúrneho dedičstva sv. Cyrila a Metoda v moderných dejinách Slovenska. Jedným z cielov štúdie je zmapovanie vplyvu cyrilo-metodského kultu v rámci religiozity spoločenských skupín a vrstiev na Slovensku. Skúmanie poukazuje na špecifiká pri uctievaní kultu Cyrila, Metoda a ich učeníkov na Slovensku a podčiarkuje vplyv dobovej cirkevno-politickej situácie na vývoj šírenia kultu, t. j. na pôsobenie politických, mocenských, cirkevných i odborných štruktúr. Pohlad na šírenie kultov v konkrétnych historických etapách Slovenska metodicky umožnil synchrónny i diachrónny prístup interdisciplinárneho výskumu. V nadväznosti na historickú analýzu sa autor pokúsi reflektovat’ presahy cyrilo-metodského kultúrneho dedičstva do nábožensko-etickej roviny. Solúnski bratia priniesli vo svojej misii východné dôrazy zbožnosti (a celkového pohladu na svet). Štúdia naznačuje definovanie viacerých aspektov diela solúnskych bratov, ktoré z hladiska
\end{abstract}

Táto práca bola podporovaná Agentúrou na podporu výskumu a vývoja na základe Zmluvy č. APVV-16-0116. 
rozvoja duchovnej podstaty spoločnosti a cirkvi zostávajú aktuálne a inšpiratívne, ako napo-

kon naznačili výsledky druhého Vatikánskeho koncilu a dokumenty Jána Pavla II.

Klúčové slová: cyrilo-metodské kultúrne dedičstvo, moderné dejiny Slovenska, religiozita

\section{Úvod}

Tradície sa vymedzujú ako silný element kultúry, ktorý mal mat prostredníctvom odovzdávania súhrnu informácií a skúseností relevantnú úlohu pri potvrdzovaní kontinuity historicky určitého spoločenstva (Krejčí 2007, 108-116). Tým sa kultúrne dedičstvo predkov začleňuje medzi účinné prvky jeho sebadefinovania. Ku kultivácii postáv predvelkomoravskej a vel'komoravskej doby došlo v náboženskom, národnom a kultúrnom živote Slovákov už počas národného obrodenia. Cyrilo-metodský fenomén bol spájaný s predstavou historickej starobylosti, kultúrnej vyspelosti a štátnej samostatnosti Slovákov. Prvý smer vývoja poznania, opierajúc sa o pramennú, dejepisnými metódami dokumentovatelnú bázu, sa dotkol predovšetkým dôrazu na politicko-kultúrno-sociálne súvislosti tohto kultu. Druhý smer predstavuje cirkevne formulovaná kontinuita. Na náboženské tradície na Slovensku môžeme nazerat na základe viacerých aspektov, napríklad na základe počtu ludí, hlásajúcimi sa $\mathrm{k}$ nim v určitej historickej etape. Dôležité sú aj hladiská veku tradícií či stavu prebádania ich historických koreňov. V období, ked’ sa vytvárali moderné identity, teda počas národného obrodenia, potrebovali určité skupiny ludí doložit konštrukty kontinuity $\mathrm{k}$ budovaniu svojej identity. V prípade úcty k svätým ide o vytvorenie nebeského „Vzoru“ a preukázanie existencie života u Boha, resp. k prepojeniu pozemského a duchovného života (Hanuš 2013, 15). Cyrilo-metodská tradícia je súčastou vel'komoravskej tradície, no cesty ich vývoja a pertraktovania $\mathrm{v}$ rôznych obdobiach neboli zhodné. Uchopenie oboch tradícií v širšom stredoeurópskom regióne v prvotných zmienkach obrodeneckých kruhov bolo odlišné od neskorších konštruktov národného príbehu. Cyrilo-metodské príbehy boli pôvodne skoro výhradne súčastou náboženskej historiografie a hagiografie (Podolan 2013, 198; Vepřek 2016, 192-198).

\section{Reflexia kultúrneho dedičstva sv. Cyrila a Metoda v religiozite Slovenska}

Z pohladu na dejinné udalosti je očividné, že historická prítomnost’ krestanstva v Európe je nespochybnitelná. Krestanstvo bolo poväčšine v strede týchto udalostí. Cirkev bola nimi raz obohatená a pozdvihnutá, inokedy zasa oslabená. Krestanské náboženstvo pretváralo etniká na civilizované spoločenstvá. Prinieslo im vieru, ale aj kultúru, vzdelanie, nový spôsob myslenia a konania. Krestanstvo umožnilo civilizáciu aj slovanským predkom prostredníctvom misie solúnskych bratov (Klobušická 2013, 576-577). Konštantín-Cyril a Metod používali na evanjelizačnú úlohu nielen klasické formy, ale aj spoločenské komunikačné prostriedky vlastné pre dobu ich misionárskeho pôsobenia. Úspech mohli dosiahnut len za predpokladu správnej služby dorozumievacích prostriedkov. Konštantín mal víziu aplikovat na misiách knihy, osobitne knihy Svätého písma, žaltára, zákonníky, misály. Predovšetkým z tohto dôvodu vytvoril staroslovienske písmo a spolu s bratom Metodom, resp. so svojimi učeníkmi zanechal po sebe rozsiahle prekladové i vlastné literárne dielo. Konštantín-Cyril a Metod boli odchovancami byzantského filozofického systému, ktorý nadväzoval a zároveň v krestanskom duchu tvorivo pretváral antické grécke a rímske dedičstvo. Je zrejmé, ako významné bolo toto dedičstvo pre celú európsku i svetovú kultúru. Paradoxne, pred vydaním priekopníckej práce gréckeho profesora Vasiliosa Tatakisa s názvom Byzantská filozofia v Parízi roku 1949 sa existencia filozofického myslenia v Byzantskej ríši neuznávala - prevládal názor, že 
Byzancia len teologizovala. Tatakis systémovo dokázal, že kozmogonické filozofické teórie antického klasického obdobia nekončia christianizáciou Grékov, ale filozofické posudzovanie problémov a metodické filozofovanie kontinuálne pokračuje a neprerušene sa rozvíja prostredníctvom konštruktívneho tvorivého myslenia byzantských spisovatelov v d’alších storočiach. Filozofická aktivita v Byzancii zahŕňala učenie, komentáre klasických textov logiky a fyziky, otázky prírody a človeka, ktoré velmi často vychádzali z učenia najvýznamnejších filozofov antického Grécka. Napriek pokrokom v komplexnejšom byzantologickom výskume (najmä pokial' ide o dejiny, jazyk a umenie), filozofické texty, ktoré sa týkajú sveta, prírody a človeka, z ktorých vychádzali solúnski bratia, boli doposial málo vydávané a skúmané, preto odborníkov čaká ešte vela práce na ich zozbieraní, vydaní a analyzovaní (Zozulak 2013, 792, 794). Práve 9. storočie je možné považovat' za začiatok byzantskej filozofie, ked' sa učenci začali dôkladne zaoberat' textami antických gréckych filozofov. Z pohladu cyrilo-metodskej misie je výskum byzantskej filozofie velmi dôležitý. Ako vysvetluje byzantológ František Dvorník (1970, 78), Konštantínova definícia filozofie ${ }^{2}$ vychádza zo stoického učenia, že vedenie spočíva v poznaní vecí božských a ludských. Druhá čast’ Konštantínovej definície pripomína Platónovu myšlienku, že človek sa má podla svojich schopností priblížit k Bohu. Na určité problémy s precenením antických vplyvov v Konštantínovom diele upozornil profesor Alexander Avenarius $(1992,71)$, podla ktorého antické prvky predstavujú len akýsi formálny rámec definície a sú podriadené myšlienke, že poznávanie má svoje oprávnenie vtedy, ked' slúži poznaniu božských vecí. V byzantskom myslení sa prelínala filozofia s teológiou a Konštantín bol aj vynikajúcim teológom. Konštantín študoval u najväčšieho učenca 9. storočia a konštantínopolského patriarchu Fótia a do istej miery mohol byt’ ovplyvnený humanistickými tendenciami daného obdobia. Zdá sa však, že humanistické prúdy nemali zásadný vplyv na jeho myslenie a vo svojich filozofických úvahách dával prednost' hlbšiemu krestanskému výkladu a opieral sa o krestanských autorov. ${ }^{3}$ Filozofia by podla Konštantína mala poukazovat na racionalitu viery. Týmto sa zaradil do tábora dialektikov, ktorí používajú logiku a filozofiu v teológii a vo viere, čo velmi dôsledne využíval v praktickej činnosti (Volek 2001, 13).

Na základe pramenného poznania je všeobecne akceptovaný názor, že najmä sv. Cyril bol neobyčajne nadaný, talentovaný, reflexná kontemplatívna osobnosti. Podla gréckej tradície spočíva vrchol ludskej dôstojnosti v poznaní. Človek svojím intelektom, rozumom prevyšuje na svete všetko ostatné, môže spoznávat dokonca i samého Boha. Podla Aristotela a Platóna bolo vrcholom filozofie vyzdvihnutie intelektu k Bohu (Špidlík 2004, 180). K základným životným hodnotám pestovaným v Byzantskej ríši patrili zodpovednost', úcta, čestnost', úprimnost', tolerancia, nezištnost', dôvera, spravodlivost', pokoj, rozvaha, láska, filantropia či priatel'stvo. Okrem hlbokých teologických a filozofických poznatkov museli byt solúnski bratia znalcami aj iných textov z byzantského obdobia, ktoré sa týkali oblasti práva, medicíny, matematiky, astronómie, teórie hudby

2 Dokazuje to aj informácia v moravsko-panónskej legende Život Konštantína, kde sa píše: „Ked’ logotet videl, aký (Konštantín) je, dal mu moc nad svojím domom a dovolil mu volne vchádzat do cisárskeho paláca. Raz sa ho opýtal: ,Filozof, rád by som vedel, čo je filozofia. 'On hned' pohotový odpovedal: ,Poznávanie božských i ludských vecí, pokial'sa človek môže približit' k Bohu, lebo uči človeka stat sa vlastnými skutkami obrazom a podobou toho, ktorý ho stvoril. 'Preto si ho tento muž, velký a vážený, ešte viac oblúbil a neprestajne sa ho vypytoval na všetko. A on mu vysvetlil filozofickú náuku a málo slovami mu objasnil jej hlboký zmysel“ (Život Konštantína 1990, 4).

3 Kedže jeho vnímanie filozofie malo teologický základ, pri objektívnom posudzovaní Konštantínovej definície filozofie musíme brat jednoznačne do úvahy dobovú teológiu. Byzantské filozofické myslenie totiž najprv v 6. storočí výrazne ovplyvnila grécka scholastika, neskôr, v 8. storočí Dialektika posledného z cirkevných otcov patristiky Jána Damaského (Zozulak 2013, 797). Konštantínovým vzorom bol sv. Gregor Naziánsky, zvaný Teológ, ktorý ho inšpiroval hlavne v jeho názore na poslanie človeka vo svete (Turzonovová 2013, 264). 
a d’alších vied. Cez vlastné diela bratov ako Proglas, Nomokánon, Zakon sudnyj ljudem a i. a potom i prostredníctvom diel ich nasledovníkov sa mohli tieto poznatky a hodnoty rozšírit do strednej Európy a následne i do iných končín. Vplyv byzantského vzdelania, kánonického a svetského práva $\mathrm{v}$ cyrilo-metodskom diele možno pozorovat’ $\mathrm{v}$ otázkach výchovy $\mathrm{k}$ týmto hodnotám, ale aj v presune antropocentrických aspektov k humanizmu, t. j. v otázke náboženskej slobody, t. j. spôsobe, akým boli pokrestančovaní Slovania, zvyšovania vzdelanostnej úrovne, rozvoji umenia, literatúry, obchodu, správania panovníkov, v rešpekte a úcte voči autoritám v spoločnosti a rodine, organizácii rodinného života, politike a diplomacii, sociálnom zabezpečení či správaniu sa $\mathrm{k}$ menšinám. Zakon sudnyj ljudem bola právnická zbierka zákonov pre súdy, právny kódex zostavený Metodom, niekdajším vysokým štátnym úradníkom, do ktorého zahrnul prvky domáceho zvykového práva ale najmä rozvinuté právo Byzantskej ríše - v tom čase vrchol európskej právnej vedy a právnej praxe. A spolu s Metodovým dielom Napomenutie vladárom to bol základ štátneho poriadku v Svätoplukovej ríši (Korec 2012, 8).

Proces prenikania a pôsobenia jednej kultúry na kultúru druhú je jav vel’mi zložitý, pokial' ho nechápeme len ako určitý kontakt, dotyk, efemérne ovplyvnenie, ale vidíme v ňom jav dlhodobého trvania a trvalejšieho zakomponovania určitých javov prechádzajúcich z odovzdávajúcej kultúry do prijímajúcej kultúry (Avenarius 1992, 11). Podstatný je však nielen synchrónny pohlad na transfer diela solúnskych bratov, ale aj na ich determináciu pri historických procesoch v perspektíve súčasných zmien. V centre rozličných transformácií a vylepšení súčasnej spoločnosti stojí človek. Vo vyhrotených situáciách dehumanizácie a degradácie človeka sa vo filozofii otvárala potreba nanovo definovat ludskú osobu a poukázat na jej hodnotu. V podstatnej miere na vytvorenie a formovanie definície osoby malo i nadalej má vplyv náboženské myslenie. Religiózne podnety sú dôležitým prvkom, ktorý nastoluje základy vnímania dôležitosti ludskej osoby (Baloghová 2015, 5). V tomto kontexte zohráva i na Slovensku významnú úlohu cyrilo-metodský kult.

Po úmrtí Metoda v roku 885 došlo k vyhnaniu jeho učeníkov z Velkej Moravy (neskoršie pôsobenie učencov vo vyhnanstve bolo klúčovým momentom vo vývine kultúry južných a východných Slovanov), rovnako aj k opätovnému zavedeniu latinčiny ako liturgického jazyka v Svätoplukovej ríši. Po vzniku Uhorska sa latinský kultúrno-náboženský kurz na území dnešného Slovenska umocnil. Cyrilo-metodský kult pomerne rýchlo nahradil nastupujúci kult uhorských svätých panovníkov i lokálnych svätcov.

Úcta k Cyrilovi a Metodovi je v Uhorsku zdokumentovaná v početnejších písomných prejavoch až od 17. storočia. Bratskú dvojicu spomína predovšetkým historická a liturgická literatúra, pričom v 17. a 18. storočí sa predstavy o ich pôsobení čiastočne ustalujú. Cyrilo-metodská i velkomoravská tradícia, viažuca sa na pamätné udalosti a slávne osobnosti ako Pribinu, Svätopluka i samotných solúnskych bratov, sa počínajúc 17. storočím stáva v slovenskom prostredí významnou súčastou barokového a neskôr obrodeneckého historizmu (Tibenský 1992, 579). ${ }^{4} \mathrm{~V}$ pozadí tohto záujmu stála okrem iného snaha uhorských cirkevných historikov dokázat', že cyrilo-metodská misia sa vztahovala nielen na územie Vel'kej Moravy, ale aj Uhorska, kedže Metod bol menovaný za moravsko-panónskeho arcibiskupa (Macho 2013, 70). Rozvíjanie cyrilo-metodskej tradície

4 V Uhorsku ako prvý spomína cyrilo-metodskú tradíciu jezuita Melchior Inchofer vo svojich Cirkevných análoch Uhorského královstva z roku 1644. K praktickému a všeobecnému propagovaniu poznatkov o svätcoch medzi kňazmi, učitelmi i veriacim ludom rozhodne prispela až dalšia písomnost'. V roku 1655 vyšiel Cantus Catholici, t. j. spevník katolíckych piesní, univerzálne využívaný pri bohoslužbách $\mathrm{v}$ takmer všetkých katolíckych farnostiach. Jeho pôvodca Benedikt Szöllösi v predslove už podrobne hovorí o sv. Cyrilovi a Metodovi ako vierozvestoch Slovákov. V prostredí cirkvi byzantského obradu bol v 16. storočí napísaný Terebliansky prológ, ktorý obsahuje aj synaxárový Život svätého Konštantína Filozofa a Život Konštantína (Žeňuch 2015, 23). 
akcentovalo celé slovenské národné hnutie. ${ }^{5} \mathrm{~V}$ slovenskom etnickom prostredí boli pre formovanie slovenskej národnej identity primárne dôležité dve zložky cirkevno-náboženského života - katolícka a evanjelická a. v. Historický cyrilo-metodský naratív sa udomácnil v kruhoch vzdelancov oboch konfesionálnych spoločenstiev, hoci v druhej polovici 18. storočia ho častejšie zdôrazňovali katolícki intelektuáli. Obaja svätci napokon symbolizovali podobu cirkvi, ktorá nebola rozštiepená schizmou a v prípade evanjelického spoločenstva poskytovali možnost̉ legitimizovat jeho existenciu, ktoré bolo náporom rekatolizácie neustále spochybňované (Kowalská 2007, 120). Evanjelickí vzdelanci sa tiež identifikovali s Velkou Moravou a Cyrila a Metoda vnímali ako zvestovatelov krestanstva medzi Slovákmi a šíritelov Božieho slova v domácom jazyku. Seba samých pokladali za pokračovatelov ich diela, pričom spojovací článok medzi nimi a sebou nachádzali v reformácii, ktorá rehabilitovala domáce jazyky a hlásala návrat k pôvodným ideálom krestanstva (Škvarna 2004, 20).

V prvej polovici 19. storočia sa percepcia misie solúnskych bratov oproti predchádzajúcim obdobiam zmenila. Reminiscencia na christianizačnú činnost’ sv. Cyrila a Metoda sa dočkala kvalitatívneho rozvoja v rámci šírenia novej kultúry, písma a jazyka a tiež v dobových konotáciách Vel'kej Moravy v politickom (štátotvornom) zmysle. Kult postupne nadobúdal viacfunkčnú podobu a najmä pod vplyvom básnického diela katolíckeho kňaza Jána Hollého zdôrazňovala cyrilo-metodský kult - osobitne jeho národno-štátnu stránku - aj generácia štúrovcov. V národno-identifikačnej interpretácii cyrilo-metodskej tradície sa štúrovci pokúšali neoddelovat národnú a náboženskú ideu. ${ }^{6} \mathrm{~V}$ 19. storočí teda nebol obraz svätcov, ktorý preferoval kultúrny význam ich misie, primárne napojený na konkrétnu konfesionalitu, čo napokon poskytlo spoločnú platformu pre spoluprácu katolíckych aj luteránskych cirkevných hodnostárov pri príprave osláv milénia ich príchodu na Vel'kú Moravu. ${ }^{7}$

Od polovice 19. storočia sa zintenzívnilo pripomínanie svätcov v tlači a na iných verejných fórach. Zasvätené a pomenované po nich boli viaceré kostoly, kaplnky, oltáre, zvony, kostolné zástavy, školy a knižnice (Škvarna - Hudek 2013, 4). Súviselo to predovšetkým s miléniovými oslavami ich príchodu na Velkú Moravu (1863), úmrtia sv. Cyrila (1869) a Metoda (1885). ${ }^{8}$ Šest'desiate roky 19. storočia sú v slovenskej histórii známe ako matičné obdobie. Pri príležitosti miléniových osláv príchodu solúnskych bratov na Vel'kú Moravu sa v roku 1863 uskutočnilo množstvo aktivít, ktoré zorganizovali predstavitelia katolíckej, ako aj evanjelickej cirkvi. Kvôli odporu cirkevnej vrchnosti

5 Postavy oboch bratov pripomínali a osvetlovali vo svojich dielach vzdelanci katolícki i evanjelickí - Daniel Sinapius-Horčička, Samuel Timon, Juraj Papánek či Juraj Sklenár. K rozvoju tradície (podčiarkujúc jej náboženský rámec) výrazne prispeli bernolákovci, najmä Juraj Fándly.

6 Ako poznamenáva historička Daniela Kodajová: „Hurban vo svojom variante podania slovenských dejín prostredníctvom vývoja literatúry, na ktorom sa podielali zástupcovia obidvoch konfesií a tí svojou činnostou akoby nadviazali na základy národnej písomnej kultúry, ktorú položili Cyril a Metod, urobil z tohto variantu dejín Slovákov spoločný príbeh." (Kodajová 2013, 90; Kodajová 2014, 85-87).

7 Súčasný historik Peter Macho postrehol, že vo významnom dokumente známom ako Memorandum národa slovenského z roku 1861, ktorý predstavitelia národného života zaslali ako svoj národnopolitický program panovníkovi, je zabudovaná tiež zmienka cyrilo-metodskej symboliky: „... Tento dištrikt jestvuje ... s dodatočne presne vymedzenými hranicami ako autonómna právomocnost', ktorá má ako ochrancov vzývat'svätých bratov Cyrila a Metoda... "Výslednej podobe tohto štátoprávneho dokumentu určila pečat teda tradičná katolícka interpretácia fenoménu svätcov, ktorá mohla dokonca pôsobit rušivo, kedže z hladiska augsburského vierovyznania je na rozdiel od katolicizmu vzývanie svätcov neprípustné. Tento príklad je svedectvom interkonfesionálneho konsenzu (Macho 2013,72-74).

8 Podla solúnskych bratov bol pomenovaný katolícky časopis Cyrill a Method. Katolický Časopis pro Cirkew a skolu, ktorý niesol v záhlaví aj ich podobizeň. Prvé číslo vyšlo v Banskej Štiavnici v roku 1850 symbolicky na sviatok sv. Cyrila a Metoda, ktorý sa v danom období slávil 14. marca. Jeho redaktorom sa stal Ján Palárik, vydavatelskej úlohy sa zhostil Andrej Radlinský. 
nakoniec slávnostné pripomenutie príchodu sv. Cyrila a Metoda malo výhradne náboženský charakter bez výraznejšieho spojenia s vlasteneckou myšlienkou. Prvé valné zhromaždenie Matice slovenskej, ktoré sa konalo 4. augusta 1863, deklarovalo, že táto inštitúcia vznikla ako pripomienka tisícročnej pamiatky pokrestančenia Slovákov. Počas slávnostnej svätej omše boli v kázni zdôraznené zásluhy sv. Cyrila a Metoda (Kohútová 2014, 65-67). Oživená tradícia ${ }^{9}$ podnietila tiež vedecké skúmanie vel'komoravskej éry.

Po rakúsko-uhorskom vyrovnaní v roku 1867 bolo pripomínanie si cyrilo-metodského kultu vzhladom na zmenenú politicko-spoločenskú situáciu zatlačené do úzadia, a to aj napriek tomu, že v roku 1880 pápež Lev XIII. (1878 - 1903) zverejnil encykliku Grande munus, v ktorej nariadil, aby sa 5. júl stal univerzálnym sviatkom uctievania sv. Cyrila a Metoda v celej katolíckej cirkvi. V posledných desatročiach 19. storočia sa až do zániku Habsburskej monarchie stretávame s prejavmi uctievania solúnskych bratov na území dnešného Slovenska sporadicky. Výnimkou boli gréckokatolícki a pravoslávni veriaci, ktorí svätcov byzantského pôvodu slávili v liturgických obradoch. ${ }^{10}$ Sprievody v slovenských mestách, kde pravdepodobne pôsobila cyrilo-metodská misia (Devín, Nitra), sa nekonali; prebiehali však v moravskom Velehrade. ${ }^{11}$ Slováci mohli v ére Uhorska nerušene a vel'mi plodne pestovat cyrilo-metodskú úctu aspoň v zahraničí, kde ich na začiatku 20. storočia žila asi tretina. Cyrilo-metodský kult sa vyvíjal tak rýchlo a intenzívne, že na konci 19. storočia sa stal jednoznačným identifikačným rysom slovenských imigrantov v Spojených štátoch amerických a Kanade. Dokazujú to kostoly, verejné budovy, školy a dokonca aj medaily / vyznamenania rôznych inštitúcií, ktoré nesú ich meno (Ženský rád sestier sv. Cyrila a Metoda založený v roku 1909). Rovnako ako kult kedysi pomohol zjednotit luteránov a katolíkov v Uhorsku, $\mathrm{v}$ americkom prostredí prispel $\mathrm{k}$ zjednoteniu rímskokatolíckych a gréckokatolíckych imigrantov zo Slovenska (Kowalská 2013, 74).

20. storočie je v histórii Slovenska charakterizované častými a výraznými zmenami. Vznik Československej republiky v roku 1918 so sebou priniesol nové možnosti a novú symboliku. Pre katolícku aj evanjelickú cirkev bola cyrilo-metodská tradícia kategorickým imperatívom. ${ }^{12}$ Náboženská úcta svätých bratov sa posilnila, na Slovensku sa na nich hladelo ako na národných

9 Rozšírenie cyrilo-metodského kultu, jeho popularita, ako aj formy jeho udržovania a uctievania skutočne vrcholili okolo roku 1863 na cirkevnej pôde, v národnom živote, $\mathrm{v}$ tlači. Rozvinul sa tak obsah a národnotvorná funkcia cyrilo-metodskej tradície. Pôvodne v nej dominoval náboženský a slovanský rozmer, postupne sa $\mathrm{v}$ oboch konfesionálnych prostrediach čoraz viac poslovenčovala, až sa stala jedným z najefektívnejších nástrojov upevnenia a manifestovania národnej emancipácie Slovákov. V tomto období sa kult Cyrila a Metoda rozvinul obsahovo, priestorovo, inštrumentálne, vizuálne, zážitkovo. Títo svätci sa ustálili ako jeden z najfrekventovanejších a najtypickejších slovenských symbolov (Lopatková 2014, 69-77).

10 Pravoslávna cirkev, zastúpená najmä na východnom Slovensku, slávi sviatok sv. Cyrila a Metoda 11. mája, teda v deň, ked’ podla tradície prišli solúnski bratia na Velkú Moravu. Gréckokatolícka cirkev vo svojom kalendári slávi sviatok dvakrát - spoločne s rímskokatolíckou cirkvou 5. júla a druhýkrát 27. júla spolu $s$ ich žiakmi ako sviatok sedmopočetníkov.

${ }_{11}$ Práve od duchovných správcov Velehradu - sušilovskej družiny a potom Tovaryšstva Ježišovho, ktoré prevzalo velehradské svätyne, vidiet' pokus učinit z cyrilo-metodského kultu modernú formu zbožnosti napojenú nielen na moravskú, ale aj celú slovanskú oblast'. Velehradskí jezuiti dokázali prehĺbit vo svojom programe slovanskú vzájomnost. V rámci unionistických zjazdov na počiatku 20. storočia dokázali naviazat rad kontaktov predovšetkým s katolíkmi vo východoslovanských a juhoslovanských krajinách, s grékokatolíkmi i niektorými pravoslávnymi. Tým potvrdili myšlienku, že na cyrilo-metodstve sa dá postavit program pre prítomnost', ktorý bude založený na odbornom výskume, kontaktoch so zahraničím a pokuse učinit katolicizmus lákavý pre krestanský Východ (Hanuš 2013, 16-17).

12 Slovensko bolo zväčša rímskokatolícke a počas medzivojnového obdobia sa podiel tohto vyznania udržiaval na úrovni $71 \%$. Druhou najpočetnejšou skupinou bola evanjelická cirkev augsburského vyznania 
patrónov, katolíci ich sviatok slávili každý rok 5. júla. V tomto duchu sa niesli i obrady vysviacky prvých slovenských biskupov po rozpade Rakúsko-uhorskej monarchie - Mariána Blahu pre Banskú Bystricu, Karola Kmetłka pre Nitru a Jána Vojtaššáka pre Spiš -, ktorí zasadli na biskupské stolce po vypovedaných mad’arských episkopoch. Slávnosti celonárodného významu, ktoré sa konali 13. februára 1921, boli poznačené hlbokou symbolikou Metodovho sídla a kontinuity katolíckej cirkvi na Slovensku. Prejavila sa v obradných ornamentoch, ako aj v rozmanitých prejavoch. Aj Klement Micara, pápežský nuncius, pozdravoval nových biskupov ako nástupcov sv. Cyrila a Metoda. Cyrilo-metodský odkaz sa vnímal ako fenomén spojený s katolicizmom aj $\mathrm{v}$ nasledujúcich rokoch, a to $\mathrm{v}$ mediálnych prezentáciách a prejavoch iných katolíckych hodnostárov. Oslabenie interkonfesionálneho konsenzu, ktorý sme mohli pozorovat v matičnom období, mohlo vyplývat aj zo zdanlivého uspokojenia z dosiahnutia určitého stupňa štátnej suverenity. V politických kruhoch však takáto konzistentnost̉ nepanovala a v nazeraní rôznych záujmových strán na vel'komoravskú (cyrilo-metodskú) tradíciu sa prejavovali značné rozpory. Časte českých prvorepublikových historikov na čele s Janom Slavíkom považovali cyrilo-metodskú tradíciu za umelo vykonštruovanú, pričom nemôže prospiet ani česko-slovenskej jednote, pretože nebol v tom čase seriózne doložený vztah bratov k Čechám (Hanuš 2013, 19-20). Československá vláda a jej oficiálna štátna ideológia čechoslovakizmu pôsobila pragmatickejšie a z cyrilo-metodskej idey vyvodzovala latentný príklad jednoty umelého československého národa na pozadí historickej spolupatričnosti Čechov a Slovákov. V cyrilo-metodskom odkaze nachádzali ideologickú platformu snahy o zjednotenie Slovákov, Čechov a Moravanov. Ich spoločné dedičstvo v ňom hladalo nielen unionistické hnutie. Niektorí slovenskí politici ako Vavro Šrobár či Milan Hodža uvažovali nad prepojením cyrilo-metodskej tradície s tradíciou svätováclavskou či svätovojtešskou tradíciou. Pri týchto tradíciách však išlo u Slovákov len o jej deklarovanie bez praktických dôsledkov (Marsina 2004, 34). Politická polarizácia spoločnosti sa podpísala aj pod vnímanie dvoch symbolov a $\mathrm{s}$ nimi spojených sviatkoch, ktoré sa v kalendári nachádzajú vedla seba - sviatky Jána Husa a sv. Cyrila a Metoda. Viacerí intelektuáli, ako napríklad Martin Rázus a iní sa usilovali presvedčit spoločnost’ o tom, že 5. a 6. júl nemajú viest' k zákopovej vojne, ale sú príležitostou a výzvou na kultivovanie vztahu k minulosti, prízvukovali komplementárnost’ obidvoch symbolov a sviatkov, ktoré nemajú spoločnost' rozdelovat', ale zjednocovat' (Macho 2013, 78). Husitský smer konštrukcie československých dejín, ktorý štátna moc z hladiska svojej deklarovanej idey urputne vyzdvihovala, sa vo väčšinovom katolíckom slovenskom prostredí ani v protestantských kruhoch na Slovensku nemal nádej presadit'. Kedže sa cyrilo-metodská tradícia živo prenášala do všetkých sfér spoločenského, náboženského, osvetového a kultúrneho života, pokusy o negovanie, prípadne marginalizovanie cyrilo-metodského kultu nemohli dosiahnut u majoritnej spoločnosti na Slovensku (najmä v jej mladších generáciách) výraznejšie úspechy. V prostredí národnostných menšín neexistoval záujem o šírenie cyrilo-metodského kultu (Michela 2018, 330-331).

Slovenské autonomistické strany (predovšetkým katolícka Hlinkova slovenská ludová strana, ktorá cyrilo-metodskú tradíciu jednostranne konfesionalizovala) preferovali namiesto pestovania česko-slovenskej vzájomnosti vlastné „hodnotnejšie“ a „využitelnejšie“ národnoemancipačné symbolické vzory, medzi ktorými získala výraznú pozíciu kultúrne staršia a „národne autentickejšia“ pribinovská, t. j. predvel'komoravská tradícia (Mulík 2011, 216), deklarujúca samobytnost’ slovenského národa. Priaznivci slovenského autonomizmu považovali Velkú Moravu za štát (starých) Slovákov, ktorý existoval nezávisle od území obývaných kmeňmi starých Čechov. Misia Cyrila a Metoda bola vyhlásená za dôkaz vysokej úrovne slovenského jazykového a kultúrneho rozvoja. Predstavitelia autonomistického prúdu v slovenskom verejnom živote sa v medzivojnových rokoch

s vyše $12 \%$. Gréckokatolícke obyvatel'stvo, ktoré sa spájalo predovšetkým s rusínskou etnickou skupinou, dosahovalo približne 6,5 \%. Kalvíni sa dostali pod hranicu 5 \% (Šprocha - Tišliar 2012, 191, 202). 
so svojim opozičným postojom vyhranili voči oficiálnej štátnej ideológii vyzdvihujúcej historickú spolupatričnosť Čechov a Slovákov, ktorá sa odvodzovala z Velkomoravskej ríše. Od roku 1927 sa na Devíne konali cyrilo-metodské oslavy - periodicky (každé dva roky), ktoré sa v tridsiatych rokoch začali čoraz viac menit na politické demonštrácie autonomistov. ${ }^{13}$

Ďalšou pamätnou udalostou v histórii Slovenska sa stala cirkevno-národná všeslovanská oslava v Nitre v roku 1933, známa ako Pribinove slávnosti. V rámci jej propagácie sa konalo množstvo sprievodných podujatí a pri tejto príležitosti vyšli i hodnotné publikácie, venované osobnosti Pribinu a cyrilo-metodskému odkazu, resp. odvekej religiozite Slovákov (Hodál 1933; Životy slovanských apoštolov 1933; Ríša vel'komoravská 1933; Katolícke Slovensko 833 - 1933; Slnce nad Nitrou 1933; Život Privinov 1933). Tisícsté výročie posviacky Pribinovho kostola (na začiatku 20. storočia sa medzi odborníkmi predpokladalo, že chrám bol posvätený v roku 833) si prišli uctit’ státisíce Slovákov. Samotné Pribinove slávnosti sa zmenili na demonštráciu za autonómiu Slovenska. Nepríjemné udalosti, vrcholiace súdnym procesom so 45 hlavnými aktérmi incidentu, sa zavŕšili až amnestiou prezidenta republiky zo 14. decembra 1935, ktorá zastavila trestné pokračovanie voči previnilcom (Arpáš 2017, 233-240; Zubácka 1997, 51-56; Bartlová 2004).

Rozšíreniu poznatkov o byzantskej misii pomáhal predovšetkým vtedajší školský systém i vedecká obec. Cyril a Metod boli v tom čase i častým námetom mnohých vynikajúcich umelcov (Ludovít Fulla, František Gibala, Maximilán Schurmann a iní). Slováci si v zásade tento kult po mnohoročnej osvete o význame cyrilo-metodskej misie v medzivojnových rokoch jednoznačne osvojili.

Národnoemancipačnou produktivitou sa vyznačuje predovšetkým obdobie prvej Slovenskej republiky (1939 - 1945). Štát v tejto súvislosti už od počiatku svojej existencie uskutočňoval podstatné kroky najmä v osvetovej činnosti. Rôzne formy osláv prostredníctvom popularizácie témy v masovom meradle postihli aj tradíciu a symboliku byzantskej misie. Medzi najvýznamnejšie kultúrne centrá, v ktorých prebiehali celoslovenské podujatia zamerané na rané dejiny slovenského etnika, po územnej strate Devína v prospech Tretej ríše, zákonite patrila Nitra. Zrejme očakávane vzišla z tunajšej pôdy iniciatíva za právne vymedzenie kultu solúnskych bratov. Dňa 16. apríla 1939 sa v nitrianskom týždenníku Svornost' objavila výzva, aby bol jeden deň v roku vyhlásený za štátny sviatok, ktorý by bol venovaný úcte sv. Konštantína-Cyrila a Metoda. Zároveň sa tu zdôrazňuje, že v každej domácnosti, v škole a v úradoch by mal byt゙ umiestnený ich obraz a na námestiach majú stát ich sochy (Svornost' 1939, 1). Slovenská vláda vyhlásila za štátny sviatok na pamiatku solúnskych bratov 5. júl, t. j. deň, ktorý im bol už skôr zasvätený v katolíckej cirkvi. Prejavom meniacich sa nálad bola aj realizácia zmien názvov ulíc či inštitúcií a výmena „nevhodných“ sôch, obrazov, symbolov, nápisov, atd. za nové symboly, medzi nimi i zobrazenia sv. Cyrila a Metoda (ŠA NR, f. ŠPÚ NR, k. 1, č. 4/1939; Palárik - Mikulášová, 2016b, 182).

K rozvoju kultu sv. Cyrila a Metoda prispeli tiež vedecké a novinárske kruhy. Jednou z tažiskových oblastí politiky HSLS bolo vzdelávanie a školstvo. Vzdelávanie tažilo z rozvoja vedeckej sféry, a to na úrovni Matice slovenskej, Štátneho archeologického ústavu, Slovenskej akadémie vied a umení a pod. Cyrilo-metodská idea našla svoj ohlas u takých vedcov, akými boli František

13 Cyrilo-metodské oslavy sa mali na Devíne konat’ aj v rámci osláv 10. výročia vzniku ČSR v roku 1928. Predstavitelia rímskokatolíckej cirkvi však odmietli paralelné bohoslužby. Tento akt vytesnenia evanjelickej zložky národa z cyrilo-metodskej tradície mal svoju dohru v roku 1939, ked' významný predstavitel' ludáckeho režimu Alexander Mach obvinil slovenských protestantov z nelojálnosti z dôvodu, že samostatne zorganizovali Štefánikove oslavy na Bradle, čo „nie je nič nové pod slnkom, lebo evanjelici už dávno spolu s nami neoslavujú pravých krest’anských svätcov, ale radšej nasledujú hlas českého kacíra“. Mesačník evanjelikov Cirkevné listy v odpovedi z júna 1939 tento pseudoargument vyvrátil pripomienkou, že ich v roku 1928 z cyrilo-metodských osláv vyhnalo „nebratské“ správanie katolíkov (Macho 2013, 79). 
Hrušovský, dalej Ján Stanislav či Daniel Rapant (Palárik - Mikulášová 2016a, 130). V roku 1941 bol založený spolok slovenských gréckokatolíkov Jednota sv. Cyrila a Metoda v Michalovciach, ktorý od roku 1942 organizoval pravidelné cyrilo-metodské oslavy s podporou ludáckeho režimu (Borza 2013, 173). Silný politický obsah majú zobrazenia svätcov, ktoré sa nachádzajú na miestach, ktoré sú vnímané ako jablko sváru medzi Slovákmi a Mad’armi. V tomto prípade sakrálna funkcia pamätníkov svätcov je prekrytá národno-identifikačnou a rozlišovacou funkciou. Za týmto účelom v roku 1941, v obci Branč v blízkosti Nitry, priamo na slovensko-madarskej hranici bolo na objednávku nitrianskeho župana Štefana Haššíka postavené monumentálne súsošie Cyrila a Metoda (zhotovené už v roku 1936 akademickým sochárom Františkom Gibalom). Mali pripomínat Slovákom na oboch stranách hranice, ich dejiny a symbolizovat nároky na obsadené územia. Kult sv. Cyrila a Metoda sa odrazil aj pri tvorbe návrhov na medaily, slovenské mince a bankovky (Pecník 2007, 225-247), rovnako aj v divadelníctve (Palárik 2017, 378).

Po vypuknutí vojny so Sovietskym zväzom v roku 1941 nastala v časti politických kruhoch určitá obava z prílišného zdôrazňovania cyrilo-metodskej tradície, lebo mala v sebe príznak slovanskej súdržnosti a kultúry Východu. Napriek tomu ale neexistovala vo všeobecnosti zásadná vôla kult Cyrila a Metoda obmedzit'.

Zánik prvej Slovenskej republiky a povojnové obnovenie Československa, resp. nadvláda komunistickej diktatúry s ateistickou ideológiou (1948 - 1989) prerušili nelimitované pestovanie cyrilo-metodskej tradície v slovenskej spoločnosti. Uctievanie sv. Cyrila a Metoda i náboženský život vo všeobecnosti sa ocitli v príkrom rozpore s postojom vládnucich vrstiev a so štátom nariadených mýtov. Bezprostredne po ukončení vojny sa opät vrátilo k oslavám na Devíne, avšak mali už iný ráz - všeslovanský deň zdôrazňoval najmä slovanskú vzájomnost'. Jedným z dôvodov oslavy tejto tradície bola skutočnost', že prichádzala z východu a mala navyše protinemecký podtón (Hudek 2012, 237).

Po roku 1948 sa v plnej miere rozvinul archeologický výskum lokalít z obdobia Velkej Moravy (Mikulčice, Staré Město, Uherské Hradiště, Nitra, Bratislava). Primárnou intenciou ich prác bolo na úrovni základného výskumu rekonštruovat’ osnovné princípy vel'komoravskej éry. Vdaka tomu sa do popredia dostal dôraz na materiálnu stránku a politicko-vojenský vývoj vel'komoravskej spoločnosti ako počiatku spoločnej česko-slovenskej štátnosti. Dosvedčuje to aj výstava archeologických objavov z čias Velkej Moravy v roku 1963, teda v jubilejnom roku 1100. výročia príchodu solúnskych bratov $\mathrm{k}$ našim predkom. Táto akcia sa uskutočnila $\mathrm{v}$ čase postupnej liberalizácie režimu, no napriek tomu tu existovala prítomnost̉ určitej politickej zdržanlivosti vzhladom na obavy, že sa budú prebúdzat’ spomienky na podobné oslavy ako v 30. rokoch, ktoré sa stali podnetom pre prejavy autonomizmu.

Hoci vtedajšie vedecké bádanie nespochybňovalo, že sv. Cyril a Metod boli misionári, v súlade s dobovými tendenciami, t. j. v duchu marxistickej ideológie sa akcentovalo predovšetkým ich kultúrno-vzdelávacie poslanie. Prítažlivé prvky pre komunisticky tvorenú politiku dejín mali najmä presahy cyrilo-metodstva ku slovanstvu, vytvorenie písma na Vel'kej Morave, súperenie s germánskymi vplyvmi a ludovost' misijného pôsobenia. Duchovné otázky a cyrilo-metodskú tradíciu vedecké bádanie odsunulo do úzadia ako málo podstatný produkt danej doby. Okrem duchovno-liturgickej roviny cyrilo-metodskej misie zostali marginalizované aj otázky vztahu k západnému pápežstvu (Šebek 2018, 111). Výnimkou sú očividne zborníky štúdií, ktoré vydal Spolok sv. Vojtecha - v roku cyrilo-metodského jubilea pod názvom Apoštoli Slovienov (Trnava 1963), pri príležitosti 1100. výročia smrti sv. Cyrila a stého výročia založenia spolku bol publikovaný zborník Dedičstvo otcov (Trnava 1969). Počas opätovného úsilia o emancipáciu Slovákov v polovici 60. rokov niektorí slovenskí historici zdôrazňovaním tzv. dualizmu Rastislavovej a Svätoplukovej ríše (Morava a Nitrava) začali vyjadrovat slovenský nárok na federalizáciu Československej 
socialistickej republiky, a to napriek tomu, že tieto závery nemali oporu v lingvistike ani v etnografii (Mulík 2011, 216).

Relatívne uvol’nenie politickej klímy v 60. rokoch 20. storočia viedlo i k príležitosti na kritické zhodnocovanie prínosu cyrilo-metodskej misie zo strany odborníkov. Platformu odborného informátora plnil v tomto období najmä najstarší teologický časopis Duchovný pastier. Časopis sa $\mathrm{v}$ jubilejnom roku pomerne intenzívne zaoberal viacerými zaujímavými parciálnymi témami. Redakcia časopisu ponúkla čitatelom vo svojom novembrovom čísle zmienku o poslednom apoštolskom liste pápeža Jána XXIII. „Magnifici eventus“, ktorým oslávil 1100. výročie príchodu sv. Cyrila a Metoda na Vel'kú Moravu. Je zaujímavé, že článok, ktorým časopis informoval svojich recipientov o zvolení nového pápeža Pavla VI., vyšiel až 5 mesiacov po tomto akte, a to vzhladom na vydanie slávnostného cyrilo-metodského trojčíslia (č. 6-8). V deviatom čísle tohto ročníka bolo publikovaných d’alších šest' príspevkov s cyrilo-metodskou tematikou (Duchovný pastier 1963). Téma misie svätých bratov sa v Duchovnom pastierovi objavuje v nasledujúcom období až v roku 1985, ked’ sa viacerými príspevkami pripomenulo 1100. výročie úmrtia sv. Metoda (Dian 2013, 296-298).

Priamu väzbu s cyrilo-metodským dedičstvom má, resp. jeho súčastou je aj uctievanie skupiny sedmopočetníkov, ktoré bolo sprvu lokálnou balkánskou záležitostou a spájalo sa hlavne s Ochridským jazerom; medzi západných a východných Slovanov sa rozšírilo najmä v druhej polovici 20. storočia a viaže sa spravidla na prostredie, ktoré bolo v minulosti pod priamym vplyvom byzantského impéria. Sviatok Cyrila a Metoda a ich učeníkov, t. j. sedmopočetníkov, bol zavedený v Československu až v roku 1971 ako sviatok sv. Gorazda a spoločníkov (Škoviera 2010, 41).

Počas normalizácie prestal vládny režim využívat velkomoravskú a cyrilo-metodskú tradíciu vo svoj prospech, naopak považoval ju za nebezpečnú, kedže sa stala dôležitým symbolom podzemnej cirkvi a katolíckeho disentu (Hudek 2012, 239). Kým v roku 1977 komunistický režim ešte skrýval pred verejnostou zriadenie nezávislej slovenskej cirkevnej provincie, v priebehu rokovaní o jej vytvorení bola „živá cyrilo-metodská tradícia“ ticho prijatá ako jeden z argumentov (Kowalská 2013, 76).

Pochopitelne, iný vývoj malo uctievanie bratov vo svete, predovšetkým v centre katolíckej cirkvi. Po druhej svetovej vojne sa začalo prejavovat väčšie úsilie o harmonizáciu náboženských tradícií, ktoré súviseli s mentálnou premenou cirkví a náboženských spoločností. Toto úsilie a motivované, podobne ako ich skoršie konfesijné ohraničovanie, politicky. Kládlo si za ciel zjednotit’ rozdelené náboženské i národné skupiny, vytvorit ekumenický priestor v najširšom zmysle tohto slova, ocenit hodnoty, ktoré sú ohrozené v dôsledku komunistickej nivelizácie. V rámci náboženského vývoja pomohol obohatit pretrvávajúcu úctu k Cyrilovi a Metodovi pápež Ján Pavol II., ktorý ich v roku 1980 prehlásil za spolupatrónov Európy. Všeobecná úcta v cirkvi sa týmto gestom umocnila, no jeho zamýšlaný ekumenický ciel je otázny, pretože podozrievavost pravoslávnej cirkvi je voči podobným akciám katolíckej cirkvi značná (Hanuš 2013, 22).

Prejavy vôle veriacich vydobyt’ si náboženskú slobodu, ktorým nedokázali v plnej miere zabránit opatrenia štátnej moci, sa najmä od polovice 80. rokov stupňovali. Počas jubilejného roku 1100. výročia Metodovej smrti sa konalo viacero významných náboženských podujatí, ktorých úradné povolenie súviselo $s$ viacerými zahraničnopolitickými i domácimi okolnostami (vyhlásenie perestrojky v Sovietskom zväze, aktivity slovanského pápeža, KBSE a i.). ${ }^{14}$ Najvýznamnejším podujatím zaiste bola pút na moravskom Velehrade, na ktorej sa 7. júla 1985 zúčastnili tisícky veriacich zo Slovenska (Šebek 2013, 111-112). Cyrilo-metodská pút sa konala aj v slovenskej Levoči, národná pút v Šaštíne (15. septembra 1985). Štátna moc v reakcii na tento vývoj iniciovala usporiadanie výstavy v Nitre o výsledkoch archeologického výskumu velkomoravskej doby

${ }^{14}$ Komunistický režim však nepovolil účast na nej pôvodne pozvanému pápežovi. 
(podobne ako v roku 1963) a konferencie o česko-slovenskej štátnosti a slovanskej kultúre. Treba tiež dodat', že stranícke a štátne miesta boli atmosférou na pútach zaskočené, čo prinieslo v prvej fáze zostrenie ideologických atakov československého propagandistického aparátu na Vatikán. Komunistické úrady vnímali ako určité politické riziko i fakt, že sa v rámci velehradskej púte prepojila reprezentácia tajnej cirkvi s predstavitelmi Charty 77 (Šebek 2018, 110).

Pre nepriazeň pomerov vo vlasti sa tažisko zveladovania cyrilo-metodskej úcty prenášalo už dávnejšie do zahraničia. To, že bol kult Cyrila a Metoda u slovenských vystahovalcov mimoriadne silný, svedčí i fakt, že počet cyrilo-metodských patrocínií v kostoloch pri slovenských komunitách v USA je porovnatelný s počtom kostolov zasvätených na Slovensku (Vragaš 1991, 96). Zvláš̉ hrob sv. Cyrila v Ríme sa stal pútnickým miestom a duchovným centrom zástupcov slovenskej emigrácie. Logickým krokom bolo založenie teologického seminára (1955), a samostatného Ústavu sv. Cyrila a Metoda (1963). Pri otvorení ústavu 15. septembra 1963 počas sviatku Panny Márie ako patrónky Slovenska bolo však vyhlásené, že panteón národných svätých zahŕňa aj dalšie postavy symbolických obrancov krajiny (Kowalská 2013, 75-76). Dôležité gesto znamenala aj návšteva pápeža Jána Pavla II. v ústave, ktorá sa uskutočnila 7. novembra 1981, pri ktorej vyzdvihol politickú aktivitu emigrantov. Kedže prejavy cyrilo-metodskej úcty zo strany exilu mali výrazný politický podtext, prispievali tým k oslabovaniu komunistickej moci na Slovensku, resp. v ČSSR.

Až rok 1989 a pád komunistickej štátostrany opätovne umožnili nedeformovaný pohlad na význam sv. Cyrila a Metoda nielen vo vede, ale i v širších spoločenských vrstvách. Postkomunistická éra umožnila vyhranit’ vedecké predstavy o misii, resp. interpretácie cyrilo-metodskej tradície ovela markantnejšie ako v minulosti. Svätí získali zaujímavú rolu v politickom diskurze, ked' boli predstavovaní výlučne ako národní patróni, ktorí priniesli krestanstvo a písomnost', nie však všetkým Slovanom všeobecne, ale konkrétne (starým) Slovákom, a z ich územia následne vykonávali christianizačný proces. Viacerí autori v tomto období publikovali množstvo diskusných príspevkov, v ktorých sa objavilo aj spochybňovanie cyrilo-metodskej tradície. Pri vzniku Slovenskej republiky v roku 1993 sa cyrilo-metodská tradícia dostáva opät do popredia verejného záujmu. Samotný štátny znak s dvojitým krížom predstavuje symbol byzantskej misie. V Preambule Ústavy Slovenskej republiky je priamo zakomponovaná zmienka o cyrilo-metodskej tradícii a slovenský parlament vyhlásil 5. júl za štátny sviatok. Symbolickým centrom cyrilo-metodského kultu sa stala Nitra, kde sa práve v tento deň koná národná pút spolu s viacerými sprievodnými podujatiami za účasti najvyšších cirkevných a štátnych predstavitel’ov.

Markantnejšia pozornost̉ tematiky Vel'kej Moravy, ale i byzantskej misie sa prejavila aj v záujme vedeckých kruhov. Nestor slovenskej mediavelistiky Richard Marsina sa k téme cyrilo-metodskej tradície v 20. storočí vyjadril niekol'kokrát. O povojnovom období píše, že jej svetská čast’ (vel'komoravská tradícia) bola chápaná ako začiatky spoločnej československej štátnosti. ${ }^{15} \mathrm{O}$ úsilí

15 „U nás sa s popieraním oprávnenosti spájania so Slovenskom a Slovákmi stretávame až po vypracovaní slovenskej ústavy, ktorá túto tradíciu pripomína. Kritici oprávnenosti prihlasovania sa Slovákov k cyrilo-metodskej tradícii neprinášajú vlastne nijaké vážne nové argumenty pre svoj názor, jednoducho to pokladajú za neoprávnené, ba až za mýtus. Verejnými hlásatelmi týchto názorov v prevažnej väčšine nie sú ludia, ktorí sa s cyrilo-metodskou tradíciou, alebo príslušným obdobím odborne, vedecky zaoberajú..." (Marsina 2004, 35). Profesor Marsina v predhovore k tretiemu vydaniu monografie Metodov boj píše aj o motivácii predovšetkým politickej, pričom možno azda pripúštat aj istý konsenzus medzinárodného charakteru. „V prítomnosti sme žial aj svedkami nebývalých postojov k činnosti cyrilo-metodskej misie, takých, aké sa $v$ minulosti (ani $v$ časoch oficiálnej dominancie marxistických historiografických názorov, či historického materializmu) nevyskytovali. Stretávame sa aj s nehistorickým označovaním cyrilo-metodskej tradície za mýtus, pričom mýtom $z$ historického hladiska nemožno nazývat to, čo je doložené historickými prameñmi“(Marsina 2012, 6-7). Marsina sa však nevyhol ani kritike iného spektra odborných prác: „Hodnotením činnosti Konštantína a Metoda sa v minulosti zaoberali vo velkej miere cirkevní historici, pre nich boli 
nových slovenských (hlavne politických) elít po roku 1989 podporovat a posilňovat národnú identitu sa detailnejšie zmienil historik Adam Hudek vo svojej pomerne rozsiahlej štúdii z roku 2012: „Velkomoravské obdobie a cyrilo-metodská tradícia patria v slovenskom národnom príbehu ku klúčovým obdobiam, a tak je celkom logické, že sa k týmto témam viazali najrôznejšie mýty a politické konštrukcie. Konštantne sú obetou silnej inštrumentalizácie“ (Hudek 2012, 229). V týchto koncepciách solúnski bratia vystupujú symbolicky ako médium súčasných politických ciel'ov.

Cyrilo-metodská tradícia u Slovákov prežila celý rad transformácií. Stretávali sme sa v minulosti a aj dnes sa stretávame s extrémnymi názormi, ktoré ich na jednej strane nekriticky mytologizujú; na opačnej strane stojí čast̉ odborníkov spochybňujúcich význam činnosti a kontinuitu ich diela v slovenských dejinách, a to vzhladom na skutočnost', že po úmrtí Metoda v roku 885 došlo k vyhnaniu ich učeníkov. Treba si však uvedomit širší kontext, pretože ich dielo v nasledujúcich stáročiach reálne determinovalo kultúru i politiku vo vývoji slovanských národov, predovšetkým v juhovýchodnej a východnej Európe.

Európska spoločnost’ sa dnes nachádza v ére posthumanizmu, postkolonializmu, postindustrializmu. Značnú polemiku prognostikov teda vyvoláva otázka, aká kultúrna a náboženská tvár spoločnosti sa sformuje, ked' societa prejde cez túto postfázu. Spoločnost’ sa v dnešnej dobe potrebuje vyrovnat's mnohými problémami, ktoré sú výsledkom dlhodobého procesu. Odhliadnuc od ekonomických otrasov sa čoraz viac dostáva do popredia kultúrna a náboženská kríza. Napriek individualizmu, ktorý sa dnes očakáva od človeka v takmer všetkých oblastiach života, sa zabúda na to, že pri formovaní silnej, individuálnej osobnosti je nevyhnutné stavat na pevných fundamentoch, koreňoch (Baloghová 2015, 65-66). Význam cyrilo-metodského diela je z tohto hladiska nadčasový a univerzálny. Na všeobecne akceptovanú axiómu, že na Slovensku sa k cyrilo-metodskej tradícii hlásia všetky cirkvi a okrem oficiálnych kruhov vo svojej kultúre aj širšie ludové vrstvy (Kalinová 2013, 133-143), je však potrebné pozriet’ sa detailnejšie. Kritickým javom zostáva fakt, že napriek proklamovanému príslušenstvu vel'kej časti obyvatelstva ku krestanským cirkvám je pozorovatelný jasný rozpor medzi touto skutočnostou a reálnym stavom žitej religiozity. V celosvetovom meradle dochádza k miešaniu rozmanitých kultúr, čo zas vyústuje do zvýšenej ochrany diverzity a identity vlastnej kultúry. V oblasti symbolov a ideí, taktiež v oblasti religiozity dochádza k novému fenoménu, ktorým je „supermarketizácia“ ideí a symbolov. Výsledkom trhového správania sa na tomto poli, ktoré bolo dovtedy skôr internou a nedotknutel’nou záležitost̉ou, je skutočnost', že religiozita sa stala trhovou komoditou a podlieha aktuálnemu výberu podla individuálnych preferencií a potrieb. Postupne tak dochádza k zloženiu si vlastnej kultúrnej a religióznej mozaiky (Baloghová 2015, 69-70 a 95).

Spoločenstvá sú dnes bezprostredne konfrontované najnovším vývojom v oblasti nových komunikačných médií či biotechnológie. Andrea Vicini a Agnes M. Brazal hovoria o vztahu medzi technológiou a spiritualitou v kontexte čoraz silnejšej túžby po transcendentne, po teologickom diskurze, obrazoch a symboloch a dopyte po hlbokom morálnom usudzovaní. ${ }^{16}$

Konštantín a Metod svätcami, a preto ich pôsobenie a život vykladali ako čisto náboženskú aktivitu (...) Ich činnost' a význam nemožno však zredukovat iba na náboženské pôsobenie“ (Marsina 2012, 12).

16 Súdnost̉ môže viest k selektívnym silne kritickým postojom a konštruktívnemu angažovaniu. Napokon krestanská obraznost Kristovho tela je biblickým a teologickým zdrojom, ktorý poskytuje cesty k rozhodovaniu alebo posilneniu kybernetických koncepcií tela smerom k solidarite zamedzením „kyber-vylúčenia“. Zdôrazňujú dôležitost' stelesnenia, pričom táto obraznost implikuje odmietnutie kyber-gnostickej antropológie, ktorá oddeluje telo od vlastnej osoby, resp. podporuje únik z telesného utrpenia. Posvätnost̉ oboch svetov a Eucharistia ako prejav Tela Kristovho nám umožňuje identifikovat možné podnety sakralizácie alebo oživenia z Ducha svätého v rámci kybernetickej spoločnosti. Ludskú túžbu po transcendencie v kybernetickom svete nenaplní hollywoodsky film. Kreatívnym spôsobom možno rozoznat prítomnost’ Ducha a posilnit túto túžbu v rámci vnímania Kristovho tela len vo vztahoch. VICINI, Andrea - BRAZAL, Agnes 
Počas výrazných premien hodnotových preferencií obyvatelov vyspelých krajín sa ludské hodnoty presunuli od dôrazu na ekonomickú prosperitu na hmotné istoty, od materialistických k postmaterialistickým hodnotám, ktorých cielom je okrem iného slobodná sebarealizácia indivídua. Jedným z dôvodov hedonistiského spôsobu života zameraného prevažne na konzum, ktorý začal narastat’ $\mathrm{v}$ súvislosti $\mathrm{s}$ nástupom industrializácie $\mathrm{s}$ technologickými progresmi v 19. storočí, je snaha o vyplnenie duševnej prázdnoty a neistoty. Konzumenstvo sa však nemôže vyrovnat pravým hodnotám a len upokojuje vnútornú prázdnotu. Proces individualizácie sa preniesol takisto aj do náboženskej sféry a má nespochybnitel’ný vplyv pri vytváraní identity človeka. Človek sa stal bohorovným, ale zároveň zranitel’ným, kedže mu postmoderná spoločnost̉ neposkytuje žiadnu transcendentnú oporu. V jej kultúre absentuje prítomnost̉ idolov. Jedným z výrazných dôsledkov zmien je sekularizácia spoločnosti s ústupom krestanskej kultúry v súčasnosti, ked človek umiestňuje na prvé miesto človeka. I z týchto dôvodov silnejú tiež desekularizačné tendencie. Religiozita sa v neskorej modernite správa predovšetkým v európskej spoločnosti paradoxne. Na jednej strane je badatelný vzostupujúci záujem o duchovno, spiritualitu a hladanie pevného orientačného a hodnotového bodu, na strane druhej stojí rovnako nezanedbatelný odklon od oficiálnych inštitucionalizovaných foriem náboženstiev a menší vplyv cirkví na politiku či spoločnost̉ ako celok (Baloghová 2015, 76-97).

Ako je možné reintegrovat’ súčasnú spoločnost', ktorá je $\mathrm{v}$ stave „vyviazanosti“ $\mathrm{z}$ tradičných politických, ekonomických a rodinných vztahov, v ktorej chýbajú pevné záchytné body, idey a vzory? Integračno-legitimujúcu funkciu v spoločnosti plní náboženstvo, ktoré by malo byt náboženstvom humanity a jeho racionálnym vyjadrením by mala byṫ individualistická morálka. Ako sa Európa vyrovná s dekompozíciou a dezintegráciou spoločnosti, ktorá prebieha nielen v kultúrnej, societálnej, religióznej oblasti, ale aj v tradičných rodinných väzbách, ovplyvní jej budúcu tvár (Baloghová 2015, 99). Vie byt v tom nápomocný kult solúnskych svätcov? Boli to oni, ktorí upozornili preložením Evanjelia sv. Jána s jeho Prológom na potrebu spojenia Božieho a ludského slova. Zosobnili Boha tým, že Božie slovo prepísali do vlastného jazyka ludí, ktorého používanie napokon schválil i pápež Hadrián II. Až o tisíc rokov neskôr bolo v katolíckej cirkvi oficiálne uznané, že Božie slovo môže byt napísané vo všetkých jazykoch sveta a Boha možno chválit v každom jazyku. ${ }^{17}$ Stalo sa tak na jednom z najdôležitejších mílnikov duchovnej obnovy v 20. storočí, na Druhom vatikánskom koncile (1962 - 1965), ktorý mal na zreteli nielen tajomstvo Krista, ale aj teologické zjednocovanie cirkví. Výsledkom koncilu je predovšetkým väčšia otvorenost̉ cirkvi k svetu, vyjadrenie sa k otázkam trvalého mieru, práv človeka, spolunažívaniu rodiny národov, postoju k iným náboženstvám, náboženskej slobody a pod., ktoré i v súčasnosti hýbu svetom (Klobušická 2013, 579). Niekolko rokov po ukončení koncilového zasadania našiel vhodný príklad v podobe postáv Cyrila a Metoda, ktoré nie sú konfliktné a môžu tak spájat všetky generácie bez ohladu na konfesionálne rozdiely, slovanský pápež Ján Pavol II. Pápež dal hned' roku 1980 nový mocný impulz k úcte sv. Cyrila a Metoda tým, že apoštolským listom Egregiae virtutis ich vyhlásil za spolupatrónov Európy popri sv. Benediktovi. K významu života a pôsobenia svätých bratov sa potom vracal často ako ku klúču jednoty Cirkvi východnej i západnej. Človek sa stal ústrednou témou pastoračnej práce Jána Pavla II. už od počiatkov jeho kňazského povolania. Okrem toho ešte ako profesor etiky na teologickej fakulte v Krakove a Lublinskej Katolíckej univerzite, kde založil pol’skú personalistikú školu, sa ústredným bodom jeho filozofického myslenia stal pojem osoba. Už pri svojich akademických počiatkoch Karol Wojtyla pri tvorení originálnych personalistických syntéz, obohacovaní tomistickej metafyziky a antropológie čerpal poznatky

M. Longing for Transcendence: Cyborgs and trans- and Posthumans. In Theological Studies, vol. 76, 2015, n. 1, 164-165.

17 V reformovaných cirkvách $\mathrm{k}$ tomu došlo hned pri ich konštituovaní. 
z fenomenológie. Bol presvedčený, že človek sa môže rozvíjat len vtedy, ak svoju pozornost’ sústredí na kladenie otázok, na túžbu po pravde, na slobodu a zodpovednost', na utrpenie, smrt', vinu a nádej, atd', čo predstavuje základnú skúsenost', cez ktorú možno odhalit podstatu ludskej bytosti. Pre Wojtylu je príznačná univerzálnost'. Snažil sa o odkrytie existencie osoby človeka v profánnej individuálno-sociálnej oblasti až po odkrývanie existencie osoby v náboženskej, sakrálnej, cirkevnej a mystickej oblasti. Ako pápež nad’alej čerpal pri realizácii svojho pontifikátu z personalistických argumentov (Baloghová 2015, 24-27). Na základe tejto formácie dokázal pri svojej náuke nájst’ vel’mi jasnú inšpiráciu v cyrilo-metodskom odkaze. $V$ tejto inšpirácii je očividná využitel’nost’ a zrozumitelnost' cyrilo-metodského kultu pre súčasné a budúce generácie.

Podla súčasného cirkevného historika Petra Zubka možno v náuke polského pápeža rozlíšit viaceré okruhy a aktuálne témy s využitím cyrilo-metodského kultu. V politicko-spoločenskej línii cítit pričinenie ich diela o upevnenie spoločných krestanských koreňov Európy - koreňov, ktoré obohatili históriu, ako aj európske inštitúcie. Vztah k tomuto spoločnému dedičstvu Východu a Západu nemá ubrat z patričnej laickosti politických štruktúr, ale môže pomôct’ uchránit kontinent pred dvojakým nebezpečenstvom - ideologickým laicizmom na jednej strane a sektárskym integralizmom na strane druhej (Zubko 2014, 107-108).

Jednou z klúčových tém magisterského úradu Jána Pavla II. bol ekumenizmus. Vo filozofickej línii Ján Pavol II. postrehol logické premisy, z ktorých vyplynul jednoznačný záver - svätí bratia porozumeli, že vlastnou zárukou dynamického vtelenia krestanskej viery do živého tkaniva nových národov je plné spoločenstvo medzi Rímom a Konštantínopolom. Ohlasovali evanjelium v mene nerozdelenej cirkvi a ich práca objala bezprostredne alebo sprostredkovane celý slovanský svet. Slovania vstúpili na svetovú scénu práve v období napätia medzi Východom a Západom, ktoré vrcholilo delením a čoskoro odtrhnutím. Od roku 1980 pápež zasvätil európsky kontinent ochrane solúnskych bratov. Vyhlásenie sv. Cyrila a Metoda za spolupatrónov celej Európy, vedla sv. Benedikta, zodpovedalo rozhodným krokom smerom k cirkevnému zjednoteniu. Túžba po jednote rozdelenej cirkvi sa prejavila vo viacerých dokumentoch polského pápeža. Rozvíjajúci sa ekumenický dialóg sa i v budúcnosti bude musiet opierat’ o odkaz sv. Cyrila a Metoda, pretože cirkev zrodená $\mathrm{z}$ ich misie mala $\mathrm{v}$ sebe vpísané všeobecné znamenie ekumenického povolania, v ktorom bratia žili. Pápež vel’mi silný motív nachádzal aj v cyrilo-metodských koreňoch s autentickými hodnotami, ktoré učinili, že ich prítomnost̉ medzi národmi bola dobročinná. Slovania vd’aka misionárom získali popri vlastnom dedičstve písaný jazyk a Písmo, ktoré nezrušilo dovtedajšie kvality, ale na nich budovalo. Pápež svojimi vyjadreniami sledoval aj pastoračnú úlohu, teda konkrétny dosah do života - vrúcna a odvážna láska svätcov ku Kristovi sa prejavila predovšetkým vo vernosti misijnému a evanjelizačnému povolaniu (Zubko 2014, 108-110). Aby mohli tradičné náboženstvá evanjeliové posolstvo v ére individualizácie komunikovat a šírit', musia na to využívat' i mediálny priestor v digitálnom svete. Okruh pôsobenia Cyrila a Metoda sa neobmedzoval výlučne na náboženskú oblast'. Z viery v Boha naznačovali praktické prínosy týkajúce sa každodenného života jednotlivca, rodiny a celého spoločenstva. Následné životné rozhodnutia mali smerovat’ k Bohu, čím kládli základy nového spoločenstva, novej spravodlivosti a pokoja (Judák - Liba 2012, 116-127). Cyrilo-metodské dedičstvo teda ponúka religiózne orientovanému obyvatel'stvu okrem iného previazanie na poznanie Svätého písma, oboznamovanie sa s krestanskou tradíciou či každodenné uplatňovanie princípov krestanského učenia a ekumenizmu.

\section{Záver}

Cyril a Metod sa v mnohých aspektoch javia ako historické postavy mimoriadne dôležité pre slovanské národy, ktoré na základe ich kultu mohli v neskoršom období založit budovanie národnej 
identity. Cyrilo-metodská tradícia u Slovákov prežila viaceré transformácie, čo bolo dôsledkom jej využívania a prispôsobovania v záujme dosiahnutia neraz politických cielov v tej či onej dobe. Pôsobenie rozličných politických systémov sa v tomto smere prejavilo v rôznej intenzite budovania cyrilo-metodského kultu. V prácach slovenských vzdelancov 17. až 19. storočia sa zdôrazňoval nielen materiálny, ale i kultúrny, vzdelanostný a literárny aspekt Velkej Moravy a byzantskej misie, ako aj jej vplyv na formovanie slovanských národov. Cyrilo-metodská a aj vel'komoravská tradícia od polovice 19. storočia prešla premenami a do popredia sa dostal národnostný, kultúrny a cirkevno-politický aspekt. Cyrilo-metodská tradícia sa pred rokom 1918 na území dnešného Slovenska nemohla nerušene pestovat', lebo niesla pre uhorské politické a cirkevné elity v sebe nebezpečný panslavizmus. Po vzniku Československa bola Vel'ká Morava prezentovaná ako prvý spoločný štát Čechov a Slovákov. Po druhej svetovej vojne sa z cyrilo-metodského kultu do popredia dostávala slovanská a kultúrna zložka; začínajú sa tiež pertraktovat’ axiologické preferencie byzantského hodnotového systému v slovanskom kultúrnom prostredí, hoci aj v súčasnosti je byzantská história a filozofia, ktorej súčastou bola aj cyrilo-metodská misia, stále málo prebádaná (Zozulak 2017, 3-11). Predovšetkým v 80. rokoch 20. storočia sa cyrilo-metodská idea stáva súčastou odporu katolíckej cirkvi voči komunistickému režimu.

Poznávanie misijnej a kultúrnej činnosti nie je zaiste ukončené a neustále sa dopĺn̆a a aktualizuje. Výskum cyrilo-metodského kultúrneho dedičstva sa $\mathrm{v}$ súčasnosti rozvíja najmä $\mathrm{v}$ širšom interdisciplinárnom zábere. V poslednom období vznikli aj preklady menej známych, no o to vzácnejších prameňov. Viaceré parciálne výskumy dotvárajú mozaiku poznania. Príspevok sa zameral najmä na korelácie s ich náboženskými aktivitami, liturgickým dielom, hoci je zrejmé, že ich činnost’ a význam nemožno zredukovat iba na náboženské pôsobenie. Pomerne aktuálnou úlohou bádatelov je podat svoje zistenia verejnosti tak, aby nevnímala cyrilo-metodský sviatok len skrz optiku ludovej veselice. Nad jeho odkazom je nevyhnutné uvažovat’ v perspektíve súčasných i nastávajúcich zmien, a to v mnohých polohách, osobnej, filozofickej, cirkevnej, pastoračnej, politicko-spoločenskej či panslovansko-európskej. Cyrilo-metodskú inšpiráciu a jej celospoločenský dosah možno využit pri takých témach ako ekumenizmus, inkulturácia a kultúra, nemala by byt ňou presiaknutá len minulost', ale aj prítomnost̉ a budúcnost'.

\section{REFERENCES}

Štátny archív v Nitre (dalej ŠA NR), fond (d’alej f.) Štátny policajný úrad Nitra (dalej ŠPÚ NR), kartón (dalej k.) 1, číslo (d’alej č.) 4/1939.

Arpáš, Róbert. (2017). Prvky cyrilo-metodskej tradície ako súčast’ Pribinovho odkazu? (Oslavy 1100. výročia krestanstva v Československu) [Elements of Cyrillo-Methodian Tradition as a Part of Pribina's Legacy? (Celebrating 1100th Anniversary of Christianity in Czechoslovakia)]. In Konštantínove listy [Constantine’s Letters], 10/1, 233-240.

Avenarius, Alexander. 1992. Byzantská kultúra v slovanskom prostredí v 6. až 12. storočí. K problému recepcie a transformácie. Bratislava.

Baloghová, Barbara et al. 2015. Religiozita v perspektíve súčasných zmien. Prešov.

Bartlová, Alena. 2004. Využitie tradícií a jubilejných osláv v propagačnej politike HSL'S v prvej polovici 30. rokov 20. storočia. In Človek a spoločnost', 7/3. Dostupné na: http://www.saske.sk/ cas/archiv/3-2004/08Bartlova.html.

Borza, Peter. 2013. Cyrilo-metodská tradícia medzi gréckokatolíkmi na Slovensku v 20. storočí. In Cyrilometodějská tradice v 19. a 20. století, období rozkvětu i snah o umlčení. Praha, 165-179. 
Dian, Daniel. 2013. Rezonancia cyrilo-metodskej tradície na stránkach duchovného pastiera v rokoch 1917 - 2012. In Bánik, Tomáš et al. Tradícia a prítomnost misijného diela sv. Cyrila a Metoda. Nitra, 275-303.

Duchovný pastier 1963. Duchovný pastier. Mesačník katolíckeho duchovenstva 38/ 6-9.

Dvornik, Francis. 1970. Byzantine missions among the Slavs. New Brunswick.

Hanuš, Jiří. 2013. Cyrilometodějství: Nesamozřejmá tradice. In Junek, Marek (ed.). Cyrilometodějská tradice v 19. a 20. století, období rozkvětu i snah o umlčení. Praha, 15-24.

Hodál, Juraj. 1930. Kostol kniežata Pribinu v Nitre. Nitra.

Hudek, Adam. 2012. Cyrilo-metodská tradícia na Slovensku v 20. storočí. In Bratia, ktorí menili svet - Konštantín a Metod. Bratislava - Nitra, 229-244.

Judák, Viliam - Liba, Peter (eds.). 2012. Od Petrovho stolca k Vel'kej Morave : Pápežské dokumenty o sv. Cyrilovi a Metodovi z rokov 868 - 2012. Trnava, 116-127.

Kalinová, Alena. 2013. Ohlasy cyrilometodějské tradice v lidové kultuře. In Mitáček, Jiří (ed.): Cyril a Metoděj - doba, život, dílo. Brno : Moravské zemské muzeum, 2013, s. 133-143.

Katolícke Slovensko 833 - 1933. Katolícke Slovensko 833 - 1933. Trnava.

Klobušická, Mária. 2013. Odkaz encykliky Jána Pavla II. Slavorum apostoli pre súčasnost'. In Bánik, Tomáš et al. Tradícia a prítomnost misijného diela sv. Cyrila a Metoda. Nitra, 576-586.

Kodajová, Daniela. 2013. Symbolická inštrumentalizácia obrazu Cyrila a Metoda v kontexte formovania národného príbehu Slovákov v 19. storočí. In Cyrilometodějská tradice v 19. a 20. století, období rozkvětu i snah o umlčení. Praha, 83-101.

Kodajová, Daniela. 2014. Cyrilo-metodská a vel'komoravská tematika v tvorbe národovcov (30. 60. roky 19. storočia). In Ideové prvky národného príbehu v dlhom 19. storočí. Bratislava, 79-89.

Kohútová, Mária. 2014. Príprava cyrilo-metodských osláv biskupom Štefanom Moyzesom roku 1863. In Ideové prvky národného príbehu v dlhom 19. storočí. Bratislava, 63-67.

Korec, Ján Chryzostom. 2012. Cyrilometodská tradícia v tisícročných dejinách Slovenska. In 1150. výročie príchodu vierozvestcov Cyrila a Metoda. Trnava, 8-19.

Kowalská, Eva. 2007. Kyrill und Method. Ihre Tradition in Politik und Geisteswelt der Slowakei. In Die Renaissance der nationalpatrone. Erinnerungskulturen in Ostmitteleuropa im 20./21. Jahrhundert. Köln, Weimar, Wien, 116-127.

Kowalská, Eva. 2013. Tradicija nacionalnych svjatych Kirilla i Mefodija Vozniknovenie i ispolzovanije v političeskoj propagande slovackogo nacionalizma. In Slavianovedenije 48/2, 68-78.

Krejčí, Marek. 2007. Dědicové národních tradic? K reinterpretacím uměleckých tradic v padesátých letech. In České, slovenské a československé dějiny 20. století II. Ústí nad Orlicí,108-116.

Lopatková, Zuzana. 2014. Cyrilo-metodská tradícia a trnavské centrum posledných bernolákovcov (do konca 19. storočia). In Ideové prvky národného príbehu v dlhom 19. storočí. Bratislava, 69-77.

Macho, Peter. 2013. Cyrilometodská tradícia na Slovensku medzi konfesionalizmom a nacionalizmom. In Junek, Marek (ed.). Cyrilometodějská tradice v 19. a 20. století, období rozkvětu i snah o umlčení. Praha, 69-82.

Marsina, Richard. 2004. Cyrilometodská tradícia na Slovensku. In Studia Historica Tyrnaviensia 5. Trnava, 25-36.

Marsina, Richard. 2012. Metodov boj. Tretie vydanie. Bratislava.

Mulik, Peter. 2011. Ideologické interpretácie cyrilo-metodskej tradície v slovenských dejinách. In Kirilo-metodievski studii. Kniga 20. Sofia, 206-218.

Michela, Miroslav. 2018. Politizace cyrilometodějského kultu. In Sláva republice! : oficiální svátky a oslavy v meziválečném Československu. Praha, 309-352. 
Palárik, Miroslav. 2017. Divadelníctvo v Nitre v rokoch 1939 - 1945. [Stage-craft in Nitra between The Years 1939-1945]. In Studia Historica Nitriensia 21/2, 366-430.

Palárik, Miroslav - Mikulášová, Alena. 2016a. Libri prohibiti: Zásahy politiky do knižnej produkcie a knižničných fondov počas druhej svetovej vojny na príklade mesta Nitra [Libri prohibit: Government interference with book production and book collections during World War II as exemplified by the city of Nitra. In Muzeológia a kultúrne dedičstvo 4/2, 117-137.

Palárik, Miroslav - Mikulášová, Alena. 2016b. Názvy ulíc a námestí v zajatí politiky. Zoznam slovenských dejatelov schválených na pomenovanie verejných priestranstiev v rokoch 1939 1945. [Names of Streets and Squares Seized by Politics. List of Slovak Personalities Approved for Naming of Public Spaces in the Period 1939 - 1945]. In Studia Historica Nitriensia 20/1, 178-211.

Pecník, Marcel. 2007. Miesto cyrilometodského motívu v mincovnej, bankovkovej a medailérskej tvorbe na Slovensku. In Poznávanie kultúrneho dedičstva sv. Cyrila a Metoda. Nitra, 225-247.

Podolan, Peter. 2013. Svätí Cyril a Metod v historiografii 1. polovice 19. storočia. In Bánik, Tomáš et al. Tradícia a prítomnost' misijného diela sv. Cyrila a Metoda. Nitra, 198-220.

Ríša velkomoravská. 1933. Ríša vel'komoravská. Sborník vedeckých prác. Praha.

Slnce nad Nitrou. 1933. Slnce nad Nitrou. Trnava.

Svornost'. 1939. Zasvätme deň sv. Cyrila a Metoda. In Svornost', 16. 4. 1939, 1.

Šebek, Jaroslav. 2013. Mobilizační potenciál duchovných tradic v Československu na př́kladu reflexe cyrilometodějské tradice v období komunistického režimu. In Junek, Marek (ed.). Cyrilometodějská tradice v 19. a 20. století, období rozkvětu i snah o umlčení. Praha, 103-115.

Šebek, Jaroslav. 2018. Mezi loajalitou církví a moci. Cyrilometodějská tradice a v období komunismu. In Cyrilometodějská tradice v novodobých dějnách. Zlín, 95-111.

Škoviera, Andrej. 2010. Svätí slovanskí sedmopočetníci. Bratislava.

Škvarna, Dušan. 2004. Začiatky moderných slovenských symbolov. K vytváraniu národnej identity od konca 18. do polovice 19. storočia. Banská Bystrica.

Škvarna, Dušan - Hudek, Adam. 2013. Cyril a Metod v historickom vedomí a pamäti 19. a 20. storočia na Slovensku. Bratislava.

Špidlík, Tomáš. 2004. Duše poutníka. Kostelní Vydří.

Šprocha, Branislav - Tišliar, Pavol. 2012. Demografický obraz Slovenska v sčítaniach ludu 1919 1940. Tribun EU.

Tibenský, Ján. 1992. Funkcia cyrilometodskej a velkomoravskej tradície v ideológii slovenskej národnosti. In Historický časopis 40/5, 579-594.

Turzonovová, Božidara. 2013. Kultúrnoantropologické reflexie misie svätých Cyrila a Metoda na našom území. In Junek, Marek (ed.). Cyrilometodějská tradice v 19. a 20. století, období rozkvětu i snah o umlčení. Praha, 263-268.

Vepřek, Miroslav. 2016. Slovanská bohoslužba v české římskokatolické církvi v současnosti jako cyrilometodějske dědictví [Slavonic Liturgy in the Present-Day Czech Roman Catholic Church As a Legacy of Cyril and Methodius]. In Konštantínove listy [Constantine's Letters] 9/1, 192-198.

Volek, Peter. 2001. Úloha filozofie v diele sv. Konštantína (Cyrila), učitela Slovanov. II. časté. In Disputationes scientificae Universitatis catholicae in Ružomberok 1/2, 3-13.

Vragaš, Štefan. 1991. Cyrilometodské dedičstvo v náboženskom, národnom a kultúrnom živote Slovákov. Zürich - Toronto - Bratislava.

Zozulak, Ján. 2013. The Study of Byzantine Philosophy and Its Expansion in Great Moravia. The 1150th Anniversary of the Mission of Saints Constantine (Cyril) and Methodius. In Filozofia 68/9, 790-799. 
Zozulak, Ján. 2017. Štúdium byzantskej filozofie v Európe v 20. storočí [The Research of Byzantine Philosophy in Europe and in Slovakia]. In Konštantínove listy [Constantine's Letters] 10/1, 3-11.

Zubácka, Ida. 1997. Nitra za prvej Československej republiky. Nitra.

Zubko, Peter. 2014. Kult svätých Cyrila a Metoda v tradícii latinskej cirkvi. Vybrané kapitoly cyrilo-metodského kultu. Ružomberok.

Žeňuch, Peter. 2015. K dejinám cyrilskej písomnej kultúry na Slovensku. Nitra.

Život Konštantína. 1990. Život Konštantína. Bratislava.

Život Privinov. 1933. Život Privinov. K 1100 ročným Privinovým slávnostiam v Nitre. Nitra.

Životy slovanských apoštolov. 1933. Životy slovanských apoštolov. Praha.

\begin{abstract}
SUMMARY: THE CYRILLO-METHODIAN CULT AND RELIGIOSITY IN SLOVAKIA FROM THE 19TH TO THE 21ST CENTURY. The Byzantine mission led by St. ConstantineCyril and his brother St. Methodius which reached Great Moravia in 863 had several dimensions. After establishing the Hungarian Kingdom, the relations between the local church representatives and Methodius's followers weakened significantly. By the end of the 10th century, there was again pressure aimed at eradicating the residues of their activities and influence. The central theme of this paper is to study how the message of the CyrilloMethodian cult had spread mainly in modern history and religiosity of Slovakia. Byzantine culture had an intense influence on the life of the Slavs. Cyrillo-Methodian literary tradition came to a standstill and the use of liturgical rites introduced by the holy brothers was disrupted for a long period of time. It is a commonly known fact that the whole era of the Slovak national revival was fuelled by the development of the Cyrillo-Methodian tradition. At that time, the cultivation of cultural values which the Great Moravian figures represented began in the religious, national and cultural life of the Slovaks. The desire to restore the unity of the Church in the Cyrillo-Methodian spirit intensified at the end of the 19th century. The efforts to unite all Christians in one faith have been embraced since the Vatican Council by Christians all over the world, but mainly by one of the greatest supporters of the Cyrillo-Methodian ideas, Pope John Paul II. John Paul II recognised the importance and contribution of the CyrilloMethodian mission to the Church, and although it had taken place more than 11 centuries ago, the spiritual values that the mission represented strongly resonated in the period after the Second Vatican Council. Apostolic and missionary activity of Saints Cyril and Methodius is mentioned in an encyclical Slavorum Apostoli (1985) written by the Pope. The CyrilloMethodian tradition is in some sense a symbol of modern ecumenism. Christian teachings of the Solun brothers enriched our culture and gave it a new dimension of humanity, freedom and timelessness. Learning about the tradition and its significance may help us to understand the current relevance of the Saints' spiritual heritage.
\end{abstract}

doc. PhDr. Martin Hetényi, PhD.

Constantine the Philosopher University in Nitra

Faculty of Arts

Institute for Research of Constantine and Methodius' Cultural Heritage

Štefánikova 67

94974 Nitra

Slovakia

mhetenyi@ukf.sk 